DOI:10.17951/h.2017.51.2.77

\begin{tabular}{lcc}
\hline \multicolumn{3}{c}{ A N N A L E S } \\
UNIVERSITATIS MARIAE CURIE-SKŁODOWSKA \\
LUBLIN - POLONIA \\
VOL.LI, 2 & SECTIOH H \\
\hline
\end{tabular}

Institute of Agricultural and Food Economics - National Research Institute, Warsaw

SZCZEPAN FIGIEL

sfigiel@uwm.edu.pl

\title{
Traditional Food Products in Poland in the Light of the Current Consumer and International Food Product Innovation Trends
}

\author{
Tradycyjne produkty żywnościowe w Polsce w świetle obecnych trendów konsumenckich i innowacyjnych \\ trendów producenckich w produktach żywnościowych
}

Key words: food markets; traditional products; innovations

Słowa kluczowe: rynki żywnościowe; produkty tradycyjne; innowacje

JEL codes: D12; M13; O52; Q13

\section{Introduction}

Market competition forces food producers to look for ways of attracting consumers. One of them is devising and offering new products, which embody attributes valuable from the consumer perspective. Such products can be seen as producer innovative responses to the consumer trends, and in fact those numerous responses constitute product innovation trends.

The goal of this paper is twofold, namely to discuss briefly recent consumer and food product innovation trends, and in this context to evaluate market innovativeness and attractiveness of so-called traditional food products (TFPs) in Poland. The key research question is to what extent the food products recognized formally due to their claimed uniqueness as traditional ones can be viewed as innovations considering their key attributes and features. It should be stressed that assessing whether consumers face an innovation depends very much on the adopted definition of innovation. For instance, according to definition by Tirole [1988], who focuses on technological in- 
novations related to product and process innovations, not necessarily every promoted market novelty can be considered as a true innovation. Taking this into account it seems that an examination of attributes and features of the traditional food products can lead to interesting findings regarding their attractiveness to the consumers and positioning of such products in the food markets. Especially, that type of findings can be useful in developing marketing strategies of food companies.

The paper is organized into three main sections. In the first one, a brief review of the recent consumer trends and their potential impact on food consumption is presented. The second section contains results of a comparative analysis of the intensity of occurrence of the food product innovations trends (FPITs) in Poland, Europe, and in the world, based on data provided by the XTC World Innovation [2015]. Finally, the third section is devoted to the consumer perception of the key attributes and features of the traditional food products (TFPs) and an evaluation of such products, listed by the Polish Ministry of Agriculture and Rural Development, in the context of general consumer and producer innovative trends using the Lancaster approach [Senauer 2001].

\section{Consumer trends and their potential impact on food demand}

The trends themselves can be viewed as changes in style and taste, which have been going for a long time [Vejlgaard 2008, p. 2]. The underlying sources of consumer trends are significant social, economic, political and technological changes, which are coming slowly, but they make profound impacts on our lives. Most of the presently observed trends are associated with the change from the industrial to the post-industrial era characterized with an increasing role of knowledge and creativity as well as with an empowerment of employees. The so-called megatrends shaping nowadays consumer behavior are connected most of all with changes regarding life expectancy, level and distribution of income, value systems of consumers, structure of employment, environmental concerns as well as with rapid development of information technologies [Figiel and Kufel 2016]. Also, certain global events like the 2008 financial crisis influence consumer behavior as well. The post-crisis consumer trends discussed in the literature are the following: anti-consumption, conscious (ethical, responsible) consumption, collaborative consumption (mesh, sharing economy), freeganism, intelligent (innovative) consumption, smart shopping, cocooning (home centralization), and non-stop [Botsman and Rogers 2012; Mróz 2014; Zalega 2013]. All these trends have a profound, two-dimensional impact on food consumption, namely:

- the way we eat (increased number of smaller and richer households implies consumption away from home and convenience);

- what we eat (better educated societies are more concerned about nutrition and health implications of food, i.e. low calories, slow food, ego food, etc.). 
Consequently, food demand can no longer be viewed as dependent only on prices, income and population of consumers. It becomes increasingly driven by non-price product attributes, from which consumers derive utility or disutility. They include nutritional content, safety and convenience characteristics, and also may represent how the product was produced, the environmental impact of production, production processes and inputs like pesticides, irradiation, and genetically modified organisms [Antle 1999]. In effect, demand for various food product categories has become strongly related to the product attributes perceived by consumers. Along with rising incomes, demand for various food product attributes is likely to be changing, however, not in the same manner for all of them, but rather as described by Engel's law. In reference to Lancaster's consumer model stylized income elasticities of food products are presented in Table 1.

Table 1. Income elasticities of demand for food products depending on their attributes

\begin{tabular}{|l|l|}
\hline \multicolumn{1}{|c|}{ Product attributes } & \multicolumn{1}{c|}{ Stylized income elasticities of demand } \\
\hline Calories & Close to zero; negative for many people \\
\hline Fat \& Cholesterol & Low; strongly negative for many people \\
\hline Nutritional/Health Value & Positive; high for many people \\
\hline Convenience & High generally; very high for some people \\
\hline Diversity \& Variety & High \\
\hline Food Safety & High \\
\hline Greenness \& Sustainability & High, especially for some people \\
\hline Natural & High for some people \\
\hline Taste & Very high for virtually everyone \\
\hline Experience & High, especially for some people \\
\hline Status \& Prestige & High, especially for some people \\
\hline Value (quality/price) & Desired even at higher incomes \\
\hline
\end{tabular}

Source: Senauer [2001].

Regarding such food product attributes as calories as well as fat and cholesterol, food producers should realize that corresponding income elasticities are low, close to zero, or even negative for many consumers. In other words, increasing consumer incomes will not translate into higher demand for products exhibiting such attributes. This is supposed to be true especially in the light of consumer trends reflecting health concerns and attitudes oriented towards reducing consumption.

The opposite side of the spectrum reflecting high or very high income demand elasticities is represented by such attributes as: nutritional and health value, convenience, diversity and variety, food safety greenness and sustainability, natural, taste, experience, and status and prestige. It means that the higher consumer incomes are, the stronger will be the demand for products with that type of attributes, what is consistent with some consumer trends. Also, it needs to be emphasized that product value understood as quality to price ratio is important no matter of income level. 


\section{Food product innovation trends in Poland and in the world}

Food producers are supposed to respond to global consumer trends by offering products consistent with the consumer expectations increasingly related to consumer population characteristics and non-price product attributes. One of the ways to meet this challenge is introducing innovative products. Variety of such products reflecting producer trends can be noticed in the contemporary food markets. In Table 2, there are 15 trends listed, grouped into 5 axes, which represent potential producer responses to consumer expectations. Exemplary descriptions of specific food product features can be found in Figiel and Kufel [2016].

The axes are meant as major domains of general consumers' expectations, which are supposed to be addressed by innovative food producers directing their market efforts eventually reflected in the formation of visible trends concerning food product attributes and features.

The occurrence of food product innovation trends (FPITs) can be identified quantitatively based on the number of new food products introduced into the markets in various countries as reported by XTC World Innovation [2015]. Results of calculations show intensity of occurrence of the distinguished trends and axes defined as percentage of new products with attributes and features reflecting consumer expectations and preferences associated with a particular FPIT (Table 2).

Table 2. Intensity of occurrence of the FPITs in Poland in comparison with Europe and the world in 2013-2014 (\%)

\begin{tabular}{|c|r|r|r|}
\hline Item & Poland & Europe & World \\
\hline The pleasure axis: & $\mathbf{5 3 . 7}$ & $\mathbf{5 6 . 8}$ & $\mathbf{5 5 . 2}$ \\
\hline - sophistication (1) & 7.2 & 19.3 & 31.2 \\
\hline - variety of senses (2) & 42.5 & 29.9 & 2.9 \\
\hline - exoticism (3) & 3.5 & 3.1 & 3.9 \\
\hline - fun (4) & 0.5 & $\mathbf{1 7 . 9}$ & 9.9 \\
\hline The health axis: & $\mathbf{2 2 . 8}$ & 9.6 & 9.6 \\
\hline - natural (5) & 8.7 & 7.4 & 1.1 \\
\hline - medical (6) & 13.0 & 0.9 & $\mathbf{6 . 6}$ \\
\hline - vegetal (7) & 1.1 & $\mathbf{5 . 9}$ & 4.6 \\
\hline The physical axis: & $\mathbf{7 . 1}$ & 4.3 & 1.6 \\
\hline- slimness (8) & 4.8 & 1.4 & 0.4 \\
\hline- energy, well-being (9) & 1.4 & 0.2 & $\mathbf{1 6 . 2}$ \\
\hline - cosmetic (10) & 0.9 & $\mathbf{1 8 . 2}$ & 10.5 \\
\hline The convenience axis: & $\mathbf{1 6 . 4}$ & 12.1 & 4.1 \\
\hline- easy to handle (11) & 13.5 & 4.4 & 1.6 \\
\hline- time saving (12) & 2.0 & 1.7 & $\mathbf{1 . 4}$ \\
\hline - nomadism (13) & 0.9 & $\mathbf{1 . 2}$ & 0.6 \\
\hline The ethics axis: & $\mathbf{0 . 0}$ & 0.6 & 0.8 \\
\hline - solidarity (14) & 0.0 & 0.6 & \\
\hline - ecology (15) & 0.0 & & \\
\hline
\end{tabular}

Source: Author's own elaboration based on XTC World Innovation [2015]. 
As it can be noticed, food product innovations representing trends belonging to pleasure axis were by far the most numerous. Fairly intensive was also occurrence of the FPITs included in the health axis. Next, in terms of occurrence, were the FPITs constituting the convenience and physical axes. The FPITs belonging to the ethics axis did not appear in Poland at all and were hardly noticeable in Europe and in the world. This may mean that demand for product with such attributes is quite premature, or food companies have paid little attention to the development of that type product innovations up to now.

Comparing intensity of occurrence of individual FPITs in Poland, Europe, and in the world some differences seem to exist, however, the variety of senses trend dominated everywhere. Relatively often observed were also food product innovations representing the sophistication, medical, easy to handle, and natural trends. On the contrary, the least intensively occurring trends were solidarity, ecology, and nomadism. Indices of the percentage similarity (PSI) calculated for Poland and Europe and the whole world are 0.79 and 0.81 , respectively. So, the intensity of the FPITs' occurrence in Poland and in rest of the world can be considered as at least similar. The PSI values calculated for axes are significantly higher, namely 0.94 and 0.97 . Thus, it can be claimed that intensity of the FPITs' occurrence in Poland displays a pattern not much different than in Europe or in the world.

\section{Polish traditional food products in the context of general consumer and producer innovative trends}

In the EU, traditional food products (TFPs) are treated as a part of the cultural heritage and based on given criteria officially registered. It is also believed that they could be important for local rural economies, hence, their production and marketing should be even publicly supported. Such point of view is somewhat controversial because market success of any food product is dependent most of all on consumer perception and acceptance. Results of a study presented by Vanhonacker et al. [2008] provide an interesting insight into this issue (Table 3).

A cross-country comparison of the TFPs consumer perception in six EU countries (including Poland) clearly shows that there are some differences in terms of significance of certain product features and attributes, but overall, it is universally positive in the case of quality and its consistence as well as taste. Prevailingly well perceived are also health and environment related attributes, whereas perceived convenience, price, and availability contribute rather negatively to the TFPs' image. The TFPs are also considered as being supportive for local economies, which suggests that they enjoy a fairly high level of social acceptance. 
Pobrane z czasopisma Annales H - Oeconomia http://oeconomia.annales.umcs.pl

Data: 26/04/2023 06:35:43

SZCZEPAN FIGIEL

Table 3. Consumer perception of the TFPs' attributes in selected European countries

\begin{tabular}{|l|c|c|c|c|c|c|c|}
\hline \multicolumn{1}{|c|}{ Item } & Belgium & France & Italy & Norway & Poland & Spain & All \\
\hline Quality & + & + & + & + & + & + & + \\
\hline Special taste & + & NS & + & + & + & + & + \\
\hline Taste & + & + & + & + & + & + & + \\
\hline Consistent quality & + & + & + & + & + & + & + \\
\hline Nutritional value & + & NS & + & + & + & NS & + \\
\hline Safety & + & NS & + & + & + & + & + \\
\hline Environment-friendly & NS & + & + & + & + & NS & + \\
\hline Supportive for local economy & NS & + & + & + & + & + & + \\
\hline Appearance & NS & NS & + & + & + & NS & + \\
\hline Healthy & NS & NS & NS & NS & + & NS & + \\
\hline Assortment & + & + & NS & NS & NS & + & + \\
\hline Ease of preparation & - & NS & NS & NS & NS & NS & - \\
\hline Low time of preparation & NS & NS & NS & NS & NS & - & - \\
\hline Availability & NS & NS & - & NS & - & NS & - \\
\hline Low price & NS & - & NS & - & - & NS & - \\
\hline
\end{tabular}

Note: “+”, “-”, "NS” signal a positive, negative or insignificant effect, respectively, on the TFPs' attribute perceptions.

Source: Vanhonacker et al. [2008].

In Poland, according to the data made publicly available by the Ministry of Agriculture and Rural Development in October 2016, there were over 1,600 TFPs officially registered. They are divided into 10 categories comprising a very diverse spectrum of products ranging from generic agricultural products, as e.g. plant varieties and animal breeds, to specific food dishes and meals, as e.g. soups and ice creams. In fact, the only common facet of the TFPs is a specific geographic identification (GI), which unfortunately does not always mean a real uniqueness because of diffusion of consumption habits. The most represented were meat products and dishes and meals categories, 22.7 and $21.1 \%$, respectively. The least represented, below $3.0 \%$, were oil and fats $(2.4 \%)$ and other products categories $(2.2 \%)$. The rest of the registered TFPs were classified as follows: bakery and pastry products $(18.8 \%)$, drinks and beverages $(10.1 \%)$, fruits and vegetables $(8.8 \%)$, dairy products $(5.9 \%)$, fishery products $(4.0 \%)$, and honeys $(4.0 \%)$.

Regional distribution of the TFPs placed in the Ministerial list is very uneven, what is probably at least partly related to preservation of the food processing and culinary traditions, which differs across the 16 regions of Poland. The largest numbers of the TFPs have been registered in the Podkarpackie (13.2\%), Małopolskie (11.2\%), Pomorskie (10.8\%), and Lubelskie (10.8\%) regions, while the smallest numbers of the TFPs have been registered in the Warmińsko-Mazurskie (1.7\%), Zachodniopomorskie (2.3\%), and Dolnośląskie (2.9\%) regions.

Apart from presence of the above mentioned traditions, another significant factor determining regional distribution of the registered TFPs seems to be the interests and engagement of the local government authorities in promoting local food econo- 
my products. Unfortunately, market positioning of any TFPs against other types of competing food products constitute a real challenge because some attributes overlap. This refers to conventional food products, eco and organic food product, and even diet and functional food products. In fact, apart from geographic identification and related tradition of consumption TFPs represent features and attributes, which are not necessarily unique and always positively perceived by consumers seeking, for example, convenient, healthy, ethical and solidarity products.

\section{Conclusions}

Two key forces shape the picture of contemporary food markets. Firstly, these are the current consumer trends, which have a two-dimensional impact on food consumption, namely the way we eat and what we eat. Secondly, producer responses to consumers' expectations including food product innovations, visibly influence supply side of the food markets. Food product innovations appearing in various countries can be viewed in terms of represented product attributes and grouped into trends. Such trends (FPITs) are not equivalent to consumer trends, however, they are clearly driven by consumers' wants and wishes, which food producers are supposed to follow. Due to innovation diffusion they are observed in many countries, even if consumer preferences can be geographically differentiated. For instance, in Poland intensity of occurrence of the 15 identified FPITs exhibits a relatively high degree of similarity in comparison with Europe and the world.

From the marketing perspective, traditional food products (TFPs) cannot be viewed as products in a market vacuum, as they are just one of many options. The only fairly clear distinctive features of the TFPs are geographic indication and reference to traditional local recipes as well as way of producing. In Poland, TFPs range from very generic fresh produce to sophisticated meals and dishes being parts of local cuisines. Because of registration TFPs are granted some kind of branding, which is rather weak considering monopolistic competition, as in fact in local food markets there are often many close, or even perfect substitutes. Nonetheless, with reference to the research question, it should be stated that TFPs have some facets of marketing innovations and appropriate market positioning of them could bring positive effects considering strong demand for differentiated, branded food products.

In terms of consumer perception, attributes and features of the TFPs can be seen mainly as being in accordance with the FPITs called natural and solidarity. But, TFPs can be successful in the food markets only if they become subjects of effective marketing strategies oriented toward promoting cultural heritage and uniqueness. Especially, smart territorial marketing embracing TFPs as sub-products of regional products (tourism, events, etc.) represents a very promising potential. Yet, the concept of TFPs seems to be superficially understood in Poland and its implementation is weekly supported by appropriate marketing actions, such as well-designed pro- 
fessional promotions, which are indispensable for building brand recognition and demand for fashionable products with a power of substitution. It should also be mentioned that there is a risk of specific "inflation" of the TFPs market attractiveness if their official number would keep growing too quickly. Results of the conducted analysis have some limitations related mainly to the fact that traditional food products constitute a very broad, inconsistent category which implies difficulties in formulating universal managerial recommendations. Hence, further research in this area should be focused on particular groups of these products and their specific attributes important for consumers.

\section{Bibliography}

Antle, J.M., The New Economics of Agriculture, “American Journal of Agricultural Economics”, vol. 81, no. 5, 1999, pp. 993-1010.

Botsman, R., Rogers, R., What's Mine Is Yours: The Rise of Collaborative Consumption, Harper Collins, New York 2012.

Figiel, S., Kufel, J., Food Product Innovation Trends and the Main Consumer Trends, "Acta Scientiarum Polonorum. Oeconomica", vol. 15, no. 3, 2016, pp. 5-14.

Mróz, B., Nowe trendy konsumenckie. Implikacje dla strategii biznesowych firm. Paper presented at the

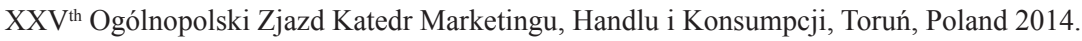

Senauer, B., The Food Consumer in the 21 $1^{\text {st }}$ Century New Research Perspectives. Working Paper 01-03, University of Minnesota, The Retail Food Industry Center, USA 2001.

Tirole, J., The Theory of Industrial Organization, The MIT Press, Cambridge MA 1988.

Vanhonacker, F., Lengard, V., Guerrero, L., Scalvedi, L., Raude, J., Zakowska, S., Hersleth, M., Verbeke, W., Europeans and Traditional Foods: Definition and Image from the Consumers'Perspective. Paper presented at the $12^{\text {th }}$ Congress of the European Association of Agricultural Economists - EAAE, Ghent, Belgium 2008.

Vejlgaard, H., Anatomy of a Trend, McGraw-Hill, NY 2008.

XTC World Innovation Panorama, XTC World Innovation 2015.

Zalega, T., Nowe trendy i makrotrendy $w$ zachowaniach konsumenckich gospodarstw domowych w XXI wieku, "Konsumpcja i Rozwój", vol. 2, no. 5, 2013, pp. 3-21.

\section{Traditional Food Products in Poland in the Light of the Current Consumer and International Food Product Innovation Trends}

Recently in the EU food markets there have appeared legally recognized products defined as traditional ones. In Poland, the Ministerial list of traditional food products (TFPs) represents a very wide spectrum of items (over 1,600 in October 2016) ranging from generic agricultural products to specific food dishes and meals. In the article an attempt to assess market attractiveness of this type of products in the light of the current consumer and international food product innovation trends was undertaken. Using the Lancaster approach to analyze attributes of the Polish TFPs it was found that they can be treated as a kind of marketing innovations, which are in line with some consumer as well as food product innovations trends. Consequently, this indicates certain marketing opportunities to be possibly taken by local food producers. 


\section{Tradycyjne produkty żywnościowe w Polsce w świetle obecnych trendów konsumenckich i innowacyjnych trendów producenckich w produktach żywnościowych}

Ostatnio na rynkach żywnościowych UE pojawiły się prawnie uznane produkty zdefiniowane jako tradycyjne. W Polsce ministerialna lista tradycyjnych produktów żywnościowych (TFPs) reprezentuje bardzo szerokie spektrum pozycji (ponad 1600 w październiku 2016 roku) od generycznych produktów rolnych do specyficznych potraw i dań. W artykule podjęto próbę oceny rynkowej atrakcyjności tego rodzaju produktów w świetle obecnych trendów konsumenckich oraz innowacyjnych trendów w produktach żywnościowych. Wykorzystując podejście Lancastera w analizie atrybutów polskich TFPs stwierdzono, że mogą być one taktowane jako pewien rodzaj innowacji marketingowych zbieżnych z niektórymi trendami konsumenckimi i innowacyjnych trendami w produktach żywnościowych. W konsekwencji oznacza to pewne marketingowe szanse, które mogą być wykorzystane przez lokalnych producentów żywności. 